\title{
DOC concentrations across a depth-dependent light gradient on a Caribbean coral reef
}

\author{
Benjamin Mueller ${ }^{\text {Corresp., }}{ }^{1,2,3}$, Erik H Meesters ${ }^{4}$, Fleur C van Duyl ${ }^{1}$ \\ 1 Department of Marine Microbiology and Biogeochemistry, NIOZ Royal Netherlands Institute for Sea Research and Utrecht University, Den Burg, The \\ Netherlands \\ 2 CARMABI Foundation, Willemstad, Curaçao \\ 3 Department of Freshwater and Marine Ecology, University of Amsterdam, Amsterdam, The Netherlands \\ 4 Wageningen Marine Research, Den Helder, The Netherlands \\ Corresponding Author: Benjamin Mueller \\ Email address: muellerb@ymail.com
}

Photosynthates released by benthic primary producers (BPP), such as reef algae and scleractinian corals, fuel the dissolved organic carbon (DOC) production on tropical coral reefs. DOC concentrations near BPP have repeatedly been observed to be elevated compared to those in the surrounding water column. As the DOC release of BPP increases with increasing light availability, elevated DOC concentrations near them will, in part, also depend on light availability. Consequently, DOC concentrations are likely to be higher on the shallow, well-lit reef terrace than in deeper sections on the fore reef slope. We measured in situ DOC concentrations and light intensity in close proximity to the reef alga Dictyota sp. and the scleractinian coral Orbicella faveolata along a depth-dependent light gradient from 5 to $20 \mathrm{~m}$ depth and compared these to background concentrations in the water column. At $10 \mathrm{~m}$ (intermediate light), DOC concentrations near Dictyota sp. were

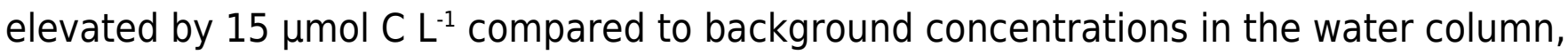
but not at 5 and $20 \mathrm{~m}$ (high and low light, respectively), or near 0 . faveolata at any of the tested depths. DOC concentrations did not differ between depths and thereby light environments for any of the tested water types. However, water type and depth appear to jointly affect in situ DOC concentrations across the tested depth-dependent light gradient. Corroborative ex situ measurements of excitation pressure on photosystem II suggest that photoinhibition in Dictyota sp. is likely to occur at light intensities that are commonly present on Curaçaoan coral reefs under high light levels at $5 \mathrm{~m}$ depth during midday. Photoinhibition may have thereby reduced the DOC release of Dictyota sp. and DOC concentrations in its close proximity. Our results indicate that the occurrence of elevated DOC concentrations did not follow a natural light gradient across depth. Instead, a combination of multiple factors, such as water type, light availability (including the restriction by photoinhibition), and water movement are proposed to interactively 
determine the DOC concentrations in the close vicinity of BPP. 
1 DOC concentrations across a depth-dependent light gradient on a Caribbean coral reef

2 Mueller $\mathrm{B}^{1,2,3}$, Meesters $\mathrm{EH}^{4}$, van Duyl FC ${ }^{1}$

3

$4 \quad{ }^{1}$ NIOZ Royal Netherlands Institute for Sea Research, Department of Marine Microbiology and 5 Biogeochemistry, and Utrecht University, Den Burg, Texel, The Netherlands.

$6 \quad{ }^{2}$ Carmabi Foundation, Willemstad, Curaçao.

7 3Present address: University of Amsterdam, Department of Freshwater and Marine Ecology,

8 Institute for Biodiversity and Ecosystem Dynamics, Amsterdam, The Netherlands.

$9 \quad{ }^{4}$ Wageningen Marine Research, Den Helder, The Netherlands.

11 Corresponding author:

12 Benjamin Mueller

14 Email address: muellerb@ymail.com 


\section{ABSTRACT}

Photosynthates released by benthic primary producers (BPP), such as reef algae and scleractinian corals, fuel the dissolved organic carbon (DOC) production on tropical coral reefs. DOC concentrations near BPP have repeatedly been observed to be elevated compared to those in the surrounding water column. As the DOC release of BPP increases with increasing light availability, elevated DOC concentrations near them will, in part, also depend on light availability. Consequently, DOC concentrations are likely to be higher on the shallow, well-lit reef terrace than in deeper sections on the fore reef slope. We measured in situ DOC concentrations and light intensity in close proximity to the reef alga Dictyota sp. and the scleractinian coral Orbicella faveolata along a depth-dependent light gradient from 5 to $20 \mathrm{~m}$ depth and compared these to background concentrations in the water column. At $10 \mathrm{~m}$ (intermediate light), DOC concentrations near Dictyota sp. were elevated by $15 \mu \mathrm{mol} \mathrm{C} \mathrm{L}-1$ compared to background concentrations in the water column, but not at 5 and $20 \mathrm{~m}$ (high and low light, respectively), or near $O$. faveolata at any of the tested depths. DOC concentrations did not differ between depths and thereby light environments for any of the tested water types. However, water type and depth appear to jointly affect in situ DOC concentrations across the tested depth-dependent light gradient. Corroborative ex situ measurements of excitation pressure on photosystem II suggest that photoinhibition in Dictyota sp. is likely to occur at light intensities that are commonly present on Curaçaoan coral reefs under high light levels at $5 \mathrm{~m}$ depth during midday. Photoinhibition may have thereby reduced the DOC release of Dictyota $\mathrm{sp}$. and DOC concentrations in its close proximity. Our results indicate that the occurrence of elevated DOC concentrations did not follow a natural light gradient across depth. Instead, a combination of multiple factors, such as water type, light availability (including the restriction by photoinhibition), and water movement are proposed to interactively determine the DOC concentrations in the close vicinity of BPP.

\section{INTRODUCTION}

Dissolved organic carbon (DOC) is the largest pool of reduced carbon on tropical coral reefs (Atkinson \& Falter 2003). A lack of a relationship between particulate organic carbon (POC as proxy for planktonic primary producers) and DOC concentrations (Tanaka et al. 2011), and increased DOC concentrations near the bottom compared to the surface water (Van Duyl \& Gast 
2001) indicate that benthic primary producers (BPP) are an important source of this DOC. Reef algae and scleractinian corals release a substantial portion of their photosynthetically fixed carbon as DOC into the surrounding water; reef algae generally release more DOC than corals (e.g., Haas et al. 2011; Haas et al. 2013b). This algal-derived DOC can promote the growth of opportunistic heterotrophic microbes in the water column as well as in the contact zone between corals and algae (Haas et al. 2013a; Haas et al. 2013b; Nelson et al. 2013). Increased microbial respiration in the coral-algal interface causes anoxia (Gregg et al. 2013; Haas et al. 2013a) in combination with the release of secondary metabolites, and can lead to tissue loss or even coral death (Barott \& Rohwer 2012; Morrow et al. 2013). Moreover, while most heterotrophic macroorganisms cannot utilize DOC for their nutrition an increasing number of reef sponges are found to predominantly rely on DOC as carbon source (Yahel et al. 2003; De Goeij et al. 2008; Mueller et al. 2014a). As with microbes, sponges also appear to prefer algal- over coral-derived DOC (Rix et al. 2016). In the so-called sponge loop these sponges utilize the energy stored in DOC and make it available to higher trophic levels via subsequent detritus production (Alexander et al. 2014; De Goeij et al. 2013). Both heterotrophic microbes and DOC-feeding sponges are therefore likely to benefit from elevated DOC concentrations with potential consequences for carbon cycling and overall coral reef functioning (e.g., Rohwer \& Youle 2010; Barott \& Rohwer 2012; De Goeij et al. 2013; Haas et al. 2016).

Elevated DOC concentrations in close proximity to BPP have been repeatedly observed on tropical coral reefs (Van Duyl \& Gast 2001; Hauri et al. 2010; Mueller et al. 2014b). However, most studies were conducted in shallow reef areas between 5 and $10 \mathrm{~m}$ and little attention was given to deeper reef sections or how DOC concentrations change across depth. Light availability decreases exponentially with depth and is an important environmental parameter that structures benthic communities across the reef slope (e.g. Bak 1974; Veron 2000; Vermeij \& Bak 2002). Light availability positively affects the DOC release rates of BPP (Crossland 1987; Haas et al. 2010b; Naumann et al. 2010; Barrón et al. 2014 and references therein). The occurrence of elevated DOC concentrations near BPP were found to be positively correlated with the availability of light (Mueller et al. 2014b). We therefore hypothesize that DOC concentrations change with depth and that elevated DOC concentrations near BPP are more likely to occur on the shallow, well-lit reef terrace $(5 \mathrm{~m})$ than at the drop off $(10 \mathrm{~m})$ or in deeper sections of the fore reef slope $(20 \mathrm{~m})$. To test this we measured in situ DOC concentrations and light intensity in 
77 close proximity to the reef alga Dictyota sp. and the scleractinian coral Orbicella faveolata

78 (former Montastraea annularis) along a depth-dependent light gradient from 5 to $20 \mathrm{~m}$ depth and compared these to background concentrations in the water column.

\section{MATERIALS AND METHODS}

Fieldwork was performed under the research permit (\#2012/48584) issued by the Curaçaoan Ministry of Health, Environment and Nature (GMN) to the CARMABI foundation.

\section{Study site and general environmental parameters}

Sampling was conducted at Snake Bay $\left(12^{\circ} 8^{\prime} \mathrm{N}, 68^{\circ} 59^{\prime} \mathrm{W}\right)$ on the leeward coast of the Island of Curaçao in the Southern Caribbean. The site consists of an approximately $100 \mathrm{~m}$ wide sandy reef terrace with patchy coral communities. The reef terrace gradually slopes towards a drop-off that starts at around $10 \mathrm{~m}$ depth. The reef then slopes down under a steep angle (20-30 ; Van Duyl (1985) and is characterized by a structurally complex reef topography. The hydrodynamics at the study site are mainly dominated by oceanic currents, which generally flows westwards along the island with approx. $50 \mathrm{~cm} \mathrm{~s}^{-1}$ (Gast et al. 1999). Due to small tidal differences (10-30 $\mathrm{cm})$ tidal currents are usually neglectable on the narrow Curaçaoan fringing reefs and water currents over the reef terraces are typically around $10-15 \mathrm{~cm} \mathrm{~s}^{-1}$.

Benthic composition was determined from 20 photo quadrats $(1 \mathrm{x} 1 \mathrm{~m})$ placed at randomized distances and alternatingly on both sides along a $30 \mathrm{~m}$ transect line. On March 24, 2017 the benthic cover following the 5, 10, and $20 \mathrm{~m}$ isobaths was recorded in the area where the DOC concentrations were quantified before (see DOC concentrations across a depth-dependent light gradient). Percentage cover of most dominant benthic components was quantified from randomly-generated overlaid points on each photograph using Coral Point Count with Excel Extensions (CPCe) (Kohler \& Gill 2006). Two photographs of the $5 \mathrm{~m}$ transect and five of the 20 $\mathrm{m}$ transect had to be excluded from be analysis due to insufficient quality.

In June, 2015 water samples to access bacterial concentrations in the water column $2 \mathrm{~m}$ off the reef slope (towards the open ocean) were taken at $15 \mathrm{~m}$ depth, following the protocol described in Dinsdale et al. (2008) to describe background bacterial abundances. Water samples $(\mathrm{n}=5)$ were transported to the nearby CARMABI research station where they were processed and analyzed (for details see Supplemental Information). 


\section{DOC concentrations across a depth-dependent light gradient}

107 To quantify DOC concentrations across a depth-dependent light gradient, water samples were 108 taken in situ in close proximity $(<5 \mathrm{~mm})$ to the reef alga Dictyota sp., the scleractinian coral $O$. 109 faveolata and the water column. Both, Dictyota sp. and O. faveolata are considered holobionts, 110 including epi- and endophytes and associated microbial communities (sensu Barott et al. 2011), 111 jointly affecting the water properties (e.g., DOC concentration) in their close vicinities. At 112 midday on July 24, 2012 between 12:00 hrs and 13:00 hrs (when light intensities are the highest) 113 patches of Dictyota sp. and colonies of $O$. faveolata were sampled at 5 (reef flat; high light), 10 114 (drop-off; intermediate light) and $20 \mathrm{~m}$ depth (fore reef slope; low light) (each $\mathrm{n}=5$ ). In 115 addition, the water column 2 m off the reef slope (towards the open ocean) was sampled $(n=5)$ 116 at the same depths and used to indicate background DOC concentrations (i.e., those not directly 117 affected by DOC release of BPP). Sampling started at $20 \mathrm{~m}$ depth and 10 and $5 \mathrm{~m}$ were sampled 118 consecutively. At each depth approx. 10 min were spent to collect all samples. The sampling 119 procedure described by van Duyl and Gast (2001) and modified by Mueller et al. (2014b) was followed. In short, water samples were collected using $100 \mathrm{ml}$ acid-washed, polypropylene syringes equipped with a flexible silicon tube attached to their tips. The tube was moved slowly above the surfaces of Dictyota sp. and O. faveolota, respectively, while collecting water (each $\mathrm{n}$ $=5)$. The water column was sampled using a similar syringes $(\mathrm{n}=5)$. All water samples were collected facing the water current to avoid potential contamination related to the diver's presence. Ambient light intensity (PAR) was recorded simultaneously while sampling (approx. $10 \mathrm{~min}$; sampling intervals $1 \mathrm{~min}$ ) using a light meter in a custom-made underwater housing (cosine LI-192SSA underwater quantum sensor connected to LI-1000 data logger; range: PAR 400-700). Water samples were transported ( $<30 \mathrm{~min})$ to the lab and stored at $4^{\circ} \mathrm{C}$ until they were processed later that same day.

\section{Processing of DOC samples}

131

Water samples collected were filtered ( $<20 \mathrm{kPa} \mathrm{Hg}$ suction pressure) over a $0.2 \mu \mathrm{m}$ polycarbonate filter (Whatman, $25 \mathrm{~mm}$ ). Prior to filtration, filters, glassware and pipette tips were rinsed three times with acid $(10 \mathrm{~mL} 0.4 \mathrm{M} \mathrm{HCl})$ and twice with sample water $(10 \mathrm{~mL})$. Afterwards $20 \mathrm{~mL}$ of sample water was filtered and the filtrate containing DOC was transferred to pre-combusted $\left(4 \mathrm{~h}\right.$ at $\left.450^{\circ} \mathrm{C}\right)$ Epa vials $(40 \mathrm{~mL})$. Samples were acidified with $6-7$ drops of 
136

137

138

139

140

141

142

143

144

145

146

147

148

149

150

151

152

153

154

155

156

157

158

159

160

161

162

163

164

concentrated $\mathrm{HCl}(38 \%)$ to remove inorganic $\mathrm{C}$ and stored at $4{ }^{\circ} \mathrm{C}$ until analysis. DOC concentrations were measured using the high-temperature catalytic oxidation (HTCO) technique in a total organic C analyzer (TOC-VCPN; Shimadzu). The instrument was calibrated with a standard addition curve of Potassium Hydrogen Phthalate $(0 ; 25 ; 50 ; 100 ; 200 \mu \mathrm{mol} \mathrm{C} \mathrm{L}-1)$. Consensus Reference Materials (CRM) provided by DA Hansell and W Chen of the University of Miami (Batch 12; 2012; 41-44 $\mu \mathrm{mol} \mathrm{C} \mathrm{L}^{-1}$ ) were used as positive controls for our measurements. Concentrations measured for the batch gave average values $( \pm \mathrm{SD})$ of $45 \pm 3 \mu \mathrm{mol}$ $\mathrm{C} \mathrm{L}^{-1}$. Average analytical variation of the instrument was $<3 \%$ (5-7 injections per sample).

\section{Maximum excitation pressure over photosystem II in Dictyota sp.}

To explore the occurrence of photoinhibition as a potential explanation for the lack of elevated DOC concentrations observed near Dictyota sp. at $5 \mathrm{~m}$ depth, an ex situ experiment to determine maximum light-dependent reduction of the effective quantum yield of photosystem II $\left(\Delta \mathrm{F} / \mathrm{Fm}{ }^{\prime}\right)$ relative to its maximum at dawn $(\mathrm{Fv} / \mathrm{Fm})$ (Iglesias-Prieto et al. 2004; Enríquez and Borowitzka 2010) was conducted. On March 16, 201730 thalli of Dictyota sp. were collected on the reef terrace (5 m depth) at Buoy $0\left(12^{\circ} 12^{\prime} 35^{\prime \prime} \mathrm{N}, 68^{\circ} 97^{\prime} 10^{\prime \prime}\right)$ and transported in a dark insulated box to the nearby CARMABI Research Station. The algae were allowed to recover and acclimatize in a flow-through seawater aquarium (flow rate: $7 \mathrm{~L} \mathrm{~min}^{-1}$ to ensure stable temperatures throughout the day) until the commencement of the experiment the following day. On March 17, 2017 at 6:00 hrs (sun rise time: 6:41 hrs; https://www.timeanddate.com) 10 thalli of Dictyota sp. were randomly selected from the aquarium and placed in a plastic dish with sea water. In the lab $\mathrm{Fv} / \mathrm{Fm}$ was measured in triplicates per thalli with a waterproof PAM fluorometer (Diving PAM, Waltz). After the measurements the thalli were discarded. Light intensity $(\mathrm{PAR})$ and water temperature $\left({ }^{\circ} \mathrm{C}\right)$ were recorded with a light logger (ODYSSEY PAR logger, Dataflow systems; sampling interval 1 min) and a temperature logger (Onset $\mathrm{HOBO}^{\circledR}$ Pendant, UA-002-08; sampling intervals $1 \mathrm{~min}$ ), respectively. After sun set, light intensity gradually increased to approximately $200 \mu \mathrm{mol}$ photons $\mathrm{m}^{-2} \mathrm{~s}^{-1}$ at 9:00 hrs (see Supplemental Information for light and temperature data). Due to the positioning of the aquarium the light intensity remained stable until 12:00 hrs, when it steeply increased to an average ( $(\mathrm{SD})$ of $1237 \pm 486 \mu \mathrm{mol}$ photons $\mathrm{m}^{-2} \mathrm{~s}^{-1}$ for the following three hours. At 15:00 hrs 10 new thalli of Dictyota sp. were randomly selected, placed in a plastic dish with sea 
165

166

167

168

169

170

171

172

173

174

175

176

177

178

179

180

181

182

183

184

185

186

187

188

189

water, and transferred to the lab. After a dark-adaptation period of 30 min to completely relax photochemical quenching, $\Delta \mathrm{F} / \mathrm{F} m$ ' was measured in triplicates per thalli.

\section{Data analysis}

Differences in DOC concentrations at the substrate-water-interface of Dictyota sp., O. faveolata and the water column from 5, 10 and $20 \mathrm{~m}$ were tested using one-way ANOVAs, followed by a Tukey HSD post-hoc test in case of significant differences. DOC concentrations were square root transformed to meet assumptions of the analysis. To further explore the combined effects of water types (Dictyota sp. and O. faveolata contact water, and water column) and depth, a twoway ANOVA was performed. The maximum excitation pressure over photosystem II $\left(\mathrm{Q}_{\mathrm{m}}\right)$ was calculated as: $\mathrm{Q}_{\mathrm{m}}=1-[(\Delta \mathrm{F} / \mathrm{F} m$ ' at noon $) /(\mathrm{F} v / \mathrm{F} m$ at dawn) $]$ (Iglesias-Prieto et al. 2004). Values that are close to zero indicate that most of the reaction centers of photosystem II remain open, whereas values close to 1.0 indicate that they are closed, suggesting photoinhibition.

\section{RESULTS}

\section{General environmental parameters}

Benthic composition differed between the three sampled depths (table 1; see Supplemental Information for benthic composition to higher taxonomic levels). While the reef terrace ( $5 \mathrm{~m}$; high light) was mainly dominated by the non-biological components sand, coral rubble, and bare coral rock, the percentage cover of scleractinian corals, macroalgae, as well as other living taxa increased at the drop off (10 m; intermediate light) and the fore reef slope ( $20 \mathrm{~m}$; low light). Similarly, with increasing depth the cover of the study organisms Dictyota sp. and O. faveolata increased from $<1 \%$ on the reef terrace to $8.8 \%$ and $2.6 \%$ at the drop off, and $5.5 \%$ and $3.0 \%$ on the fore reef slope, respectively.

Table 1 Community composition (\%) of most abundant benthic components at the study site at 5, 10, and $20 \mathrm{~m}$ depth. Percentage cover of the studied reef alga Dictyota sp. and the scleractinian coral Orbicella faveolata are given below.

\begin{tabular}{|l|c|c|c|}
\hline & \multicolumn{3}{|c|}{ Percentage cover (\%) } \\
\hline Benthic component & $5 \mathrm{~m}$ & $10 \mathrm{~m}$ & $20 \mathrm{~m}$ \\
\hline
\end{tabular}




\begin{tabular}{|l|c|c|c|}
\hline Macroalgae & 0.3 & 14.0 & 31.7 \\
\hline Turf algae & 0.0 & 9.3 & 3.0 \\
\hline Crustose coralline algae & 0.0 & 3.5 & 6.8 \\
\hline Cyanobacteria & 0.0 & 6.6 & 5.3 \\
\hline Scleractinian corals & 1.9 & 24.4 & 32.7 \\
\hline Fire corals & 0.0 & 0.6 & 0.3 \\
\hline Soft corals/gorgonians & 0.0 & 0.3 & 0.3 \\
\hline Sponges & 0.3 & 1.5 & 6.0 \\
\hline Tunicates & 0.0 & 0.1 & 0.0 \\
\hline Sand & 73.5 & 23.1 & 6.3 \\
\hline Bare coral rock & 11.0 & 4.3 & 6.3 \\
\hline Coral rubble & 13.1 & 11.1 & 1.2 \\
\hline Studied taxa: & 0.4 & 2.6 & 3.0 \\
\hline Dictyota sp. & & & 5.5 \\
\hline Orbicella faveolata & 0.1 & \multicolumn{2}{|l|}{} \\
\hline
\end{tabular}

191 Mean bacterial concentration $( \pm \mathrm{SD})$ in the water column at $15 \mathrm{~m}$ depth was $9.6 \pm 1.2 \times 10^{5}$ cells $192 \mathrm{~mL}^{-1}$.

\section{DOC concentrations across a depth-dependent light gradient}

194 At 10 m depth (intermediate light), mean in situ DOC concentration in close proximity to the reef

195 alga Dictyota sp. was 13 and $11 \mu \mathrm{mol} \mathrm{L}-1$ higher than for the scleractinian coral O. faveolata 196 (Tukey HSD, p=0.001) and the water column (Tukey HSD, p=012), respectively (Figure 1 and 197 Supplemental Information for raw data). 


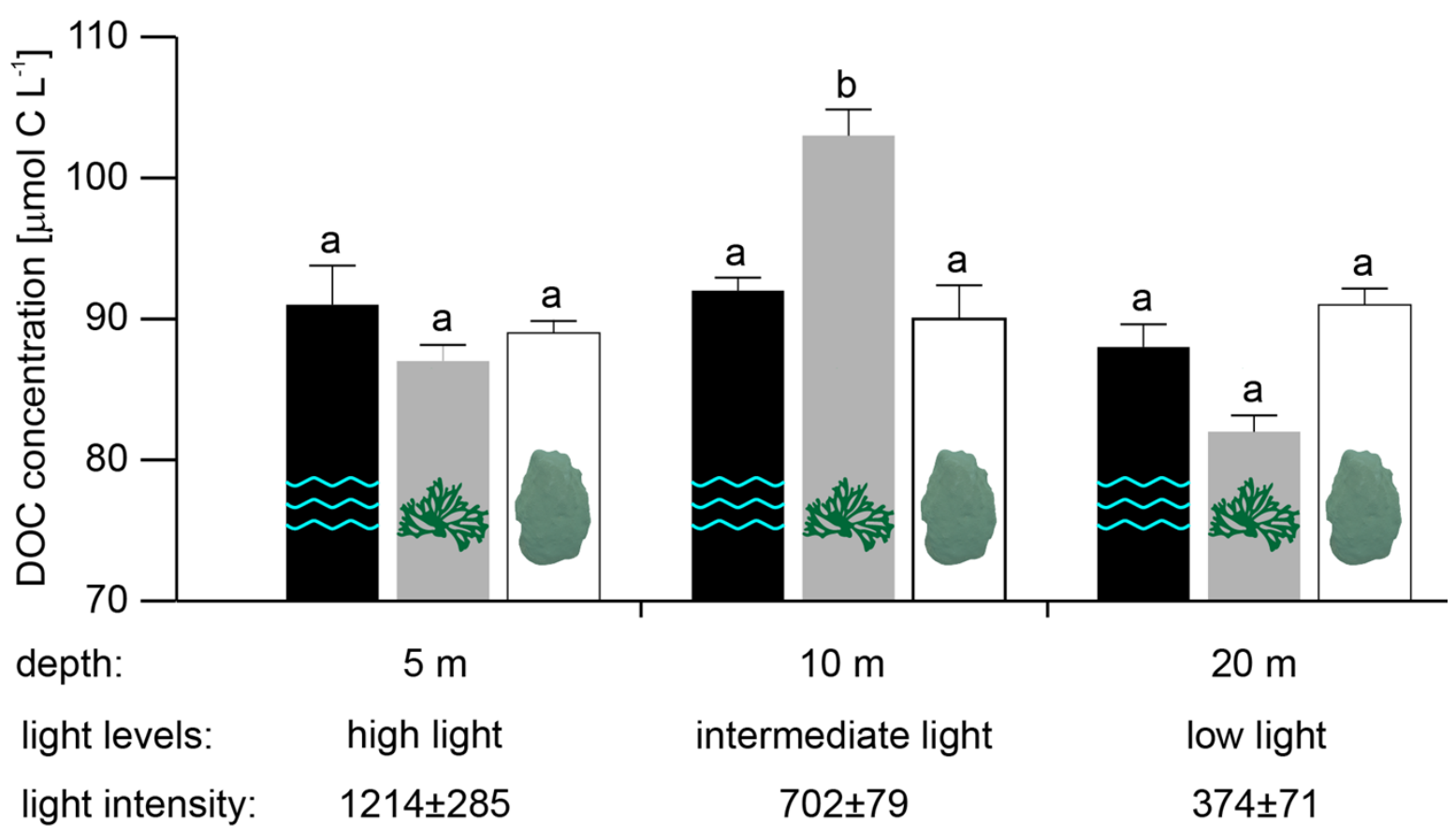

199

200 Figure 1 Mean in situ DOC concentrations $(\mathrm{n}=\mathbf{5}$, except for water column at $10 \mathrm{~m}$ and

Dictyota sp. at $5 \mathrm{~m}$ depth with $\mathrm{n}=4$ ) measured in the water column ( $2 \mathrm{~m}$ off the reef slope;

202

203

204

205

206

207

208

209

210

211

black) and at the substrate-water interfaces of the reef algae Dictyota sp. (dark grey) and the scleractinain coral Orbicella faveolata (white) at 5, 10, and $20 \mathrm{~m}$ depth. Error bars indicate SE.

Different letters indicate differences between water types for each depth (Tukey HSD, $\mathrm{p}<0.05$ ). Light intensities (mean $\pm \mathrm{SD}$ ) during the sampling are given in $\mu$ mol photons $\mathrm{m}^{-2} \mathrm{~s}^{-1}$.

In contrast, mean in situ DOC concentration at $5 \mathrm{~m}$ (high light) and $20 \mathrm{~m}$ (low light) did not differ significantly between water types (Table $2 \mathrm{~A}$ ). While mean DOC concentrations in close proximity to Dictyota sp. at $20 \mathrm{~m}$ appear to be depleted relative to concentrations in the water column and near O. faveolata, these differences were not found to be significant (Figure 1). No depth-related differences in mean DOC concentrations were established in any of the tested water types (Table 2B). 
212 Table 2 Results of one-way ANOVAs on the effect of (A) water type (per depth) and (B)

213 depth (per water type) on observed mean in situ DOC concentrations. Significant effects are 214 marked with an asterisk.

\begin{tabular}{|c|c|c|c|c|}
\hline \multicolumn{4}{|c|}{ A. Differences between water types } & \\
\hline Per depth: & df & $\mathbf{F}$ & $\mathbf{p}$ & \\
\hline High light (5 m) & 2 & 0.357 & 0.707 & \\
\hline Intermediate light (10 m) & 2 & 13.378 & 0.001 & $*$ \\
\hline Low light (20 m) & 2 & 0.129 & 0.880 & \\
\hline \multicolumn{4}{|c|}{ B. Differences between depth: } & \\
\hline Per water type: & df & $\mathbf{F}$ & $\mathbf{p}$ & \\
\hline Water column & 2 & 0.148 & 0.864 & \\
\hline Dictyota sp. & 2 & 3.682 & 0.06 & \\
\hline Orbicella faveolata & 2 & 2.798 & 0.101 & \\
\hline
\end{tabular}

215

216 However, both water type and depth appear to jointly affect mean in situ DOC concentrations 217 along the tested depth-dependent light gradient (significant interaction: water type $\mathrm{x}$ depth,

$218 \mathrm{p}=0.026$; Table 3). The sampling depths 5, 10, and $20 \mathrm{~m}$ corresponded to a light intensity of $2191214 \pm 285,702 \pm 79$ and $374 \pm 71 \mu$ mol photons $\mathrm{m}^{-2} \mathrm{~s}^{-1}$ (mean $\pm \mathrm{SD}$ ), respectively, during the 220 sampling (between 12:00 and 13:00 hrs).

222 Table 3 Results of a two-way ANOVA on the combined effects of water type and depth on 223 observed mean in situ DOC concentrations.

\begin{tabular}{|l|c|c|c|c|}
\hline Factor & df & F & p & \\
\hline Water type & 2 & 4.731 & 0.015 & $*$ \\
\hline
\end{tabular}




\begin{tabular}{|l|c|c|c|c|}
\hline Depth & 2 & 0.054 & 0.947 & \\
\hline Water type x Depth & 4 & 3.169 & 0.026 & $*$ \\
\hline
\end{tabular}

225 Maximum excitation pressure over photosystem II in Dictyota sp.

226 At dawn, maximum potential quantum yield $(\mathrm{F} v / \mathrm{Fm})$ in Dictyota sp. was $0.65 \pm 0.04$ (mean $\pm \mathrm{SD}$ ), 227 which was reduced by $67 \%$ to $0.44 \pm 0.09$ at 15:00 (effective quantum yield; $(\Delta \mathrm{F} / \mathrm{F} m$ ')

228 (Supplemental Information for raw data). The corresponding $Q_{m}$ value of 0.33 indicates foremost 229 closed reaction centers of photosystem II and thus suggest the occurrence of photoinhibition at 230 light levels of $1237 \pm 486 \mu \mathrm{mol}$ photons $\mathrm{m}^{-2} \mathrm{~s}^{-1}$, which are comparable to those observed in situ on 231 the reef terrace at $5 \mathrm{~m}$ depth (high light) during midday (see DOC concentrations across a depth232 dependent light gradient).

\section{DISCUSSION}

234

In this study we investigated DOC concentrations in close proximity to the reef alga Dictyota sp., the scleractinian coral $O$. faveolata, and in the water column across a depth-dependent light gradient between 5 and $20 \mathrm{~m}$. Due to the positive relationship between light availability and DOC release we hypothesized that DOC concentrations near BPP are highest on the shallow, well-lit reef terrace and decrease along the fore reef slope following a depth-dependent pattern. Elevated DOC concentrations compared to the background concentrations in the water column were only observed near Dictyota sp. at an intermediate depths at $10 \mathrm{~m}$, but not at $5 \mathrm{~m}$ or $20 \mathrm{~m}$ depth, or near O. faveolata at any of the tested depth. No depth- and therefore light-related differences in mean DOC concentrations were established in any of the tested water types, however, water type and depth appear to jointly affect in situ DOC concentrations across the tested depth-dependent light gradient.

Elevated DOC concentrations in close proximity to BPP occur when DOC release exceeds removal processes. Consequently, environmental parameters, such as light availability (Haas et al. 2010b; Barrón et al. 2012), temperature (Gillooly et al. 2001; Haas et al. 2010b), grazing pressure (Berman \& Holm-Hansen 1974), senescence (Khailov \& Burlakova 1969), nutrient availability (Lopéz-Sandoval et al. 2011; Mueller et al. 2016), and hydrodynamic conditions (Wild et al. 2012) affect the DOC release of BPP. In combination with factors which affect the 
251 accumulation/removal of DOC near them (e.g. morphology of the BPP, hydrodynamic

252 conditions (Losee \& Wetzel 1993, Escartín \& Aubrey 1995) and DOC consumption by

253 heterotrophic microbes and sponges (Gast et al. 1999; Yahel et al. 2003; Scheffers et al. 2005;

254 De Goeij et al. 2008, Haas et al. 2011, Nelson et al. 2013), these parameters interactively

255 determine the DOC concentrations in close vicinity to BPP. The lack of elevated DOC

256 concentrations near Dictyota sp. under high light levels at $5 \mathrm{~m}$ depth could thus be explained by

257 (1) reduced DOC release, (2) high DOC removal, or (3) a combination of both.

258 Light availability is generally considered to have a strong positive effect on DOC release of reef

259 algae. However, Haas et al. (2010b) reported that this positive correlation in the reef alga

260 Caulerpa sp. only held until a maximum light intensity was reached. At these light intensities

261 DOC release rates steeply decreased to levels comparable to those in the dark. They explained

262 this decrease with the onset of photoinhibition at a species-specific light intensity, which is a

263 common phenomenon in coral reef BPP (Franklin 1994; Hanelt et al. 1994; Brown et al. 1999;

264 Hoegh-Guldberg \& Jones 1999; Iglesias-Prieto et al. 2004). While the occurrence of

265 photoinhibition wasn't specifically tested for during the DOC sampling, the corroborative ex situ

266 experiment to assess excitation pressure over photosystem II in Dictyota sp. suggests that

267 photoinhibition can occur at light levels comparable to those observed in situ at $5 \mathrm{~m}$ depth on the

268 aforementioned sampling day. Accordingly, photoinhibition may have reduced the DOC release

269 of Dictyota sp. on the reef terrace at $5 \mathrm{~m}$ depth and therefore contributed to the fact that no

270 elevated DOC concentrations in its close proximity were found.

271

272

273

274

275

276

277

278

279

280

Similar to light availability, hydrodynamic conditions can affect in situ DOC concentrations near BPP in two ways. Either positively, when water movement increases the metabolism and DOC release rates of BPP by alleviating the limitation of the diffusive boundary layer around them (Carpenter et al. 1991; Lesser et al. 1994; Wild et al. 2012), or negatively, when water movement and water exchange hamper the accumulation of DOC by dilution (Hauri et al. 2010). Water movement generally decreases exponentially as a function of depth (Shashar et al. 1996) and significantly higher water movement rates are reported at 5 compared to 10 or $20 \mathrm{~m}$ depth on the reef slope of Curaçao (Vermeij \& Bak 2003). Thus, a reduced DOC release rate of Dictyota sp. due to photoinhibition in combination with high water movement and water exchange that hamper the accumulation of DOC, could explain the lack of elevated DOC concentrations near 
281 Dictyota $\mathrm{sp}$. under high light levels at $5 \mathrm{~m}$ depth. It can be further assumed that the negative 282 effect of water movement and water exchange on the accumulation of DOC at $10 \mathrm{~m}$ was higher

283

284

285

286

287

288

289

290

291

292

293

294

295

296

297

298

299

300

301

302

303

304

305

306

307

308

309

310

311

than at $20 \mathrm{~m}$, i.e., a higher DOC release rate was necessary to result in elevated DOC

concentrations at $10 \mathrm{~m}$. Yet, despite higher water movement, elevated DOC concentrations near Dictyota sp. were only found at 10 , but not at $20 \mathrm{~m}$. One explanation for this difference is that DOC release rates were higher at $10 \mathrm{~m}$ (intermediate light) than at $20 \mathrm{~m}$ (low light), which is in line with the aforementioned positive relation between light availability and DOC release. Interestingly, whilst not significant, DOC concentrations in close proximity to Dictyota sp. at 20 $\mathrm{m}$ depth tend to be depleted compared to concentrations near O. faveolata or in the water column. Reduced water movement and thus a prolonged water residence time combined with a low, but steady release of bio-available algal DOC (Nelson et al. 2013) by Dictyota sp., could have stimulated the growth of heterotrophic microbial communities. The bio-available DOC could have further allowed those communities to metabolize otherwise refractory components of the DOC pool and thereby deplete the local DOC stock, as described for the water columns overlying algal-dominated reefs (Dinsdale et al. 2008; Haas et al. 2016).

No elevated DOC concentrations were observed near the scleractinian coral $O$. faveolata at any of the sampling depths. In general, the DOC release of scleractinian corals is more variable than that of reef algae and an increasing number of studies suggest that scleractinian corals only contribute marginally to the local DOC pool on tropical coral reefs (e.g., Haas et al. 2010a; Naumann et al. 2010; Haas et al. 2011). Furthermore, the massive morphology of O. faveolata is less likely to restrict water exchange than the bushy thalli of Dictyota sp. and is thereby less favorable for the accumulation of DOC in its vicinity (Stocking et al. 2016). Given the positive effect of light availability on the DOC release by BPP, we expected to find significantly higher DOC concentrations on the shallow and well-lit reef terrace compared to deeper reef sections, following the natural light gradient across depth. Yet, no significant differences in the mean DOC concentrations between the sampled depths were observed, neither in close vicinity to the BPP Dictyota sp. or O. faveolata, nor in the water column. Nevertheless, both water type and depth (and thereby light availability) seem to have interactively determined in situ DOC concentrations. This is in accordance with previous findings that suggest that DOC release by, and in situ DOC concentrations near BPP are at least partly determined by a substrate-specific relationship with light availability (Mueller et al. 2014b). The absence of significant differences 
312 in DOC concentrations across the water column was also observed in other studies (Torréton et

313 al. 1997; Nelson et al. 2011). To date only Slattery \& Lesser (2015) reported a significant decline

314 in DOC concentration with depth from coral reefs on the Bahamas, albeit this decrease occurred

315 at mesophotic depths below $30 \mathrm{~m}$. This may indicate that at least above mesophotic depths, DOC

316 released by BPP is either quickly mixed and diluted throughout the reef overlying water column

317 and/or taken up by DOC feeding organisms (i.e. heterotrophic bacteria and reef sponges). The

318 abundances of open reef sponges and microbes at our study site, and on Curaçaoan reefs in

319 general, are fairly low (Gast et al. 1999; De Goeij \& Van Duyl 2007; Mueller et al. 2014a; De

320 Bakker et al. 2017) compared to abundances at more degraded locations throughout the

321 Caribbean (e.g., Pawlik et al. 2015 and references therein, Haas et al. 2016). However, DOC

322 removal by cryptic sponges living underneath overhangs and in coral cavities, which were not

323 recorded in this study, is estimated to be in the same order of magnitude as gross primary

324 production on these reefs (De Goeij et al. 2013).

325

326

327

328

329

330

331

332

333

334

335

336

337

338

339

340

\section{CONCLUSION}

While light availability has a strong positive effect on the DOC release of BPP, the occurrence of elevated DOC concentrations near them did not follow a natural light gradient across the reef slope in our study system. Instead, a combination of multiple factors, including water type, light availability, which affects the release of DOC (including the restriction by photoinhibition), and water movement, which affects the accumulation/removal of DOC, are proposed to interactively determine the DOC concentrations in the close vicinity of BPP along the reef slope.

\section{ACKNOWLEDGEMENTS}

We thank the staff of Carmabi for their hospitality and logistic support during the field work. We further thank V. Chamberland, T. Holtrop, Y. Mulders, E. van der Ent, R. van der Zande and K. Vane for their help during the field work. We are grateful to S. Gonzalez for his contribution to the DOC analysis. The manuscript benefitted greatly from comments by M. Vermeij on earlier versions of the manuscript.

\section{REFERENCES}

Alexander BE, Liebrand K, Osinga R, van der Geest HG, Admiraal W, Cleutjens JP, Schutte B, Verheyen F, Ribes M, van Loon E, and de Goeij JM. 2014. Cell turnover and detritus 
341

342

343

344

345

346

347

348

349

350

351

352

353

354

355

356

357

358

359

360

361

362

363

364

365

366

367

368

369

production in marine sponges from tropical and temperate benthic ecosystems. PLoS One 9:e109486. 10.1371/journal.pone.0109486

Atkinson MJ, and Falter JL. 2003. In: Black KD, and Shimmield GB, eds. Biogeochemistry of marine systems. Oxford: Blackwell Publishing.

Bak RPM. 1974. Available light and other factors influencing growth of stony corals through the year in Curacao: Proc. 2nd Int. Coral Reef Symp., 1974 2: p. 229-233.

Barott KL, Rodriguez-Brito B, Janouskovec J, Marhaver KL, Smith JE, Keeling P, and Rohwer FL. 2011. Microbial diversity associated with four functional groups of benthic reef algae and the reef-building coral Montastraea annularis. Environmental Microbiology 13:1192-1204. 10.1111/j.1462-2920.2010.02419.x

Barott KL, and Rohwer FL. 2012. Unseen players shape benthic competition on coral reefs. Trends in Microbiology 20:621-628. 10.1016/j.tim.2012.08.004

Barrón C, Apostolaki E, and Duarte C. 2012. Dissolved organic carbon release by marine macrophytes. Biogeosciences Discuss 9:1529-1555. doi:10.5194/bgd-9-1529-2012

Barrón C, Apostolaki ET, and Duarte CM. 2014. Dissolved organic carbon fluxes by seagrass meadows and macroalgal beds. Frontiers in Marine Science 1. 10.3389/fmars.2014.00042

Berman T, and Holm-Hansen O. 1974. Release of photoassimilated carbon as dissolved organic matter by marine phytoplankton. Marine Biology 28:305-310. 10.1007/BF00388498

Brown BE, Ambarsari I, Warner ME, Fitt WK, Dunne RP, Gibb SW, and Cummings DG. 1999. Diurnal changes in photochemical efficiency and xanthophyll concentrations in shallow water reef corals : evidence for photoinhibition and photoprotection. Coral Reefs 18:99105. $10.1007 / \mathrm{s} 003380050163$

Carpenter RC, Hackney JM, and Adey WH. 1991. Measurements of primary productivity and nitrogenase activity of coral reef algae in a chamber incorporating oscillatory flow. Limnology and Oceanography 36:40-49. 10.4319/lo.1991.36.1.0040

Crossland CJ. 1987. In situ release of mucus and DOC-lipid from the corals Acropora variabilis and Stylophora pistillata in different light regimes. Coral Reefs 6:35-42. 10.1007/BF00302210 
370

371

372

373

374

375

376

377

378

379

380

381

382

383

384

385

386

387

388

389

390

391

392

393

394

395

396

397

398

399

400

De Bakker DM, van Duyl FC, Bak RP, Nugues MM, Nieuwland G, Meesters EH (2017) 40 Years of benthic community change on the Caribbean reefs of Curaçao and Bonaire: the rise of slimy cyanobacterial mats. Coral Reefs 1-13.

De Goeij JM, Van Duyl FC. 2007. Coral cavities are sinks of dissolved organic carbon (DOC). Limnology and Oceanography 52:2608-2617.

De Goeij JM, van den Berg H, van Oostveen MM, Epping EHG, and van Duyl FC. 2008. Major bulk dissolved organic carbon (DOC) removal by encrusting coral reef cavity sponges. Marine Ecology Progress Series 357:139-151. 10.3354/meps07403

De Goeij JM, van Oevelen D, Vermeij MJA, Osinga R, Middelburg JJ, de Goeij AFPM, and Admiraal W. 2013. Surviving in a marine desert: The sponge loop retains resources within coral reefs. Science 342:108-110. 10.1126/science.1241981

Dinsdale EA, Pantos O, Smriga S, Edwards RA, Angly F, Wegley L, Hatay M, Hall D, Brown E, Haynes M, Krause L, Sala E, Sandin SA, Thurber RV, Willis BL, Azam F, Knowlton N, and Rohwer F. 2008. Microbial ecology of four coral atolls in the northern Line Islands. PLoS One 3:e1584. 10.1371/journal.pone.0001584

Enríquez S, and Borowitzka MA. 2010. The use of the fluorescence signal in studies of seagrasses and macroalgae. Chlorophyll a fluorescence in aquatic sciences: methods and applications: Springer, 187-208.

Escartin J, and Aubrey DG. 1995. Flow Structure and Dispersion within Algal Mats. Estuarine, Coastal and Shelf Science 40:451-472. http://dx.doi.org/10.1006/ecss.1995.0031

Franklin LA. 1994. The effects of temperature acclimation on the photoinhibitory responses of Ulva rotundata Blid. Planta 192:324-331.

Gast GJ, Jonkers PJ, van Duyl FC, and Bak RPM. 1999. Bacteria, flagellates and nutrients in island fringing coral reef waters: Influence of the ocean, the reef and eutrophication. Bulletin of Marine Science 65:523-538.

Gillooly JF, Brown JH, West GB, Savage VM, and Charnov EL. 2001. Effects of size and temperature on metabolic rate. Science 293:2248-2251. 10.1126/science.1061967

Gregg AK, Hatay M, Haas AF, Robinett NL, Barott K, Vermeij MJA, Marhaver KL, Meirelles P, Thompson F, and Rohwer F. 2013. Biological oxygen demand optode analysis of coral reef-associated microbial communities exposed to algal exudates. PeerJ 1:e107.

10.7717/peerj.107 
401

402

403

404

405

406

407

408

409

410

411

412

413

414

415

416

417

418

419

420

421

422

423

424

425

426

427

428

429

Haas A, Jantzen C, Naumann M, Iglesias-Prieto R, and Wild C. 2010a. Organic matter release by the dominant primary producers in a Caribbean reef lagoon: implication for in situ $\mathrm{O} 2$ availability. Marine Ecology Progress Series 409:27-39. 10.3354/meps08631

Haas AF, Naumann MS, Struck U, Mayr C, el-Zibdah M, and Wild C. 2010b. Organic matter release by coral reef associated benthic algae in the Northern Red Sea. Journal of Experimental Marine Biology and Ecology 389:53-60. http://dx.doi.org/10.1016/j.jembe.2010.03.018

Haas AF, Nelson CE, Wegley Kelly L, Carlson CA, Rohwer F, Leichter JJ, Wyatt A, and Smith JE. 2011. Effects of coral reef benthic primary producers on dissolved organic carbon and microbial activity. PLoS One 6:e27973. 10.1371/journal.pone.0027973

Haas AF, Gregg AK, Smith JE, Abieri ML, Hatay M, and Rohwer F. 2013a. Visualization of oxygen distribution patterns caused by coral and algae. PeerJ 1:e106. 10.7717/peerj.106

Haas AF, Nelson CE, Rohwer F, Wegley-Kelly L, Quistad SD, Carlson CA, Leichter JJ, Hatay M, and Smith JE. 2013b. Influence of coral and algal exudates on microbially mediated reef metabolism. PeerJ 1:e108. 10.7717/peerj.108

Haas AF, Fairoz MF, Kelly LW, Nelson CE, Dinsdale EA, Edwards RA, Giles S, Hatay M, Hisakawa N, and Knowles B. 2016. Global microbialization of coral reefs. Nature Microbiology:16042.

Hanelt D, Li J, and Nultsch W. 1994. Tidal dependence of photoinhibition of photosynthesis in marine macrophytes of the South China Sea. Botanica Acta 107:66-72.

Hauri C, Fabricius KE, Schaffelke B, and Humphrey C. 2010. Chemical and physical environmental conditions underneath mat- and canopy-forming macroalgae, and their effects on understorey corals. PLoS One 5:e12685. 10.1371/journal.pone.0012685

Hoegh-Guldberg O, and Jones RJ. 1999. Photoinhibition and photoprotection in symbiotic dinoflagellates from reef-building corals. Marine Ecology Progress Series 183:73-86.

Iglesias-Prieto R, Beltran V, LaJeunesse T, Reyes-Bonilla H, and Thome P. 2004. Different algal symbionts explain the vertical distribution of dominant reef corals in the eastern Pacific. Proceedings of the Royal Society of London, Series B: Biological Sciences 271:17571763. 
430

431

432

433

434

435

436

437

438

439

440

441

442

443

444

445

446

447

448

449

450

451

452

453

454

455

456

457

458

Khailov KM, and Burlakova ZP. 1969. Release of dissolved organic matter by marine seaweeds and distribution of their total organic production to inshore communities. Limnology and Oceanography 14:521-527. 10.4319/1o.1969.14.4.0521

Kohler KE, and Gill SM. 2006. Coral Point Count with Excel extensions (CPCe): A Visual Basic program for the determination of coral and substrate coverage using random point count methodology. Computers \& Geosciences 32:1259-1269. https://doi.org/10.1016/j.cageo.2005.11.009

Lesser MP, Weis VM, Patterson MR, and Jokiel PL. 1994. Effects of morphology and water motion on carbon delivery and productivity in the reef coral, Pocillopora damicornis (Linnaeus): Diffusion barriers, inorganic carbon limitation, and biochemical plasticity. Journal of Experimental Marine Biology and Ecology 178:153-179. http://dx.doi.org/10.1016/0022-0981(94)90034-5

Lopéz-Sandoval D, Fernandéz A, and Marañón E. 2011. Dissolved and particulate primary production along a longitudinal gradient in the Mediterranean Sea. Biogeosciences Discuss 8:815-825.

Losee RF, and Wetzel RC. 1993. Littoral flow rates within and around submersed macrophyte communities. Freshwater Biology 29:7-17. 10.1111/j.1365-2427.1993.tb00739.x

Morrow KM, Liles MR, Paul VJ, Moss A, and Chadwick NE. 2013. Bacterial shifts associated with coral-macroalgal competition in the Caribbean Sea. Marine Ecology Progress Series 488:103-117. 10.3354/meps10394

Mueller B, de Goeij JM, Vermeij MJ, Mulders Y, van der Ent E, Ribes M, and van Duyl FC. 2014a. Natural diet of coral-excavating sponges consists mainly of dissolved organic carbon (DOC). PLoS One 9:e90152. 10.1371/journal.pone.0090152

Mueller B, van der Zande RM, van Leent PJM, Meesters EH, Vermeij MJA, and van Duyl FC. 2014b. Effect of light availability on dissolved organic carbon release by Caribbean reef algae and corals. Bulletin of Marine Science 90:875-893. 10.5343/bms.2013.1062

Mueller B, den Haan J, Visser PM, Vermeij MJA, and van Duyl FC. 2016. Effect of light and nutrient availability on the release of dissolved organic carbon (DOC) by Caribbean turf algae. Sci Rep 6:23248. 10.1038/srep23248 
459 Naumann MS, Haas A, Struck U, Mayr C, el-Zibdah M, and Wild C. 2010. Organic matter

460

461

462

463

464

465

466

467

468

469

470

471

472

473

474

475

476

477

478

479

480

481

482

483

484

485

486

487

488

489 release by dominant hermatypic corals of the Northern Red Sea. Coral Reefs 29:649-659. 10.1007/s00338-010-0612-7

Nelson CE, Alldredge AL, McCliment EA, Amaral-Zettler LA, and Carlson CA. 2011. Depleted dissolved organic carbon and distinct bacterial communities in the water column of a rapid-flushing coral reef ecosystem. Isme j 5:1374-1387. 10.1038/ismej.2011.12

Nelson CE, Goldberg SJ, Wegley Kelly L, Haas AF, Smith JE, Rohwer F, and Carlson CA. 2013. Coral and macroalgal exudates vary in neutral sugar composition and differentially enrich reef bacterioplankton lineages. Isme j 7:962-979. 10.1038/ismej.2012.161

Pawlik JR, McMurray SE, Erwin P, and Zea S. 2015. A review of evidence for food limitation of sponges on Caribbean reefs. Marine Ecology Progress Series 519:265-283. 10.3354/meps 11093

Rix L, de Goeij JM, van Oevelen D, Struck U, Al-Horani FA, Wild C, and Naumann MS. 2016. Differential recycling of coral and algal dissolved organic matter via the sponge loop. Functional Ecology:n/a-n/a. 10.1111/1365-2435.12758

Rohwer F, and Youle M. 2010. Coral reefs in the microbial seas: Plaid Press.

Scheffers SR, Bak RPM, and Duyl FCv. 2005. Why is bacterioplankton growth in coral reef framework cavities enhanced? Marine Ecology Progress Series 299:89-99. 10.3354/meps299089

Shashar N, Kinane S, Jokiel PL, and Patterson MR. 1996. Hydromechanical boundary layers over a coral reef. Journal of Experimental Marine Biology and Ecology 199:17-28. http://dx.doi.org/10.1016/0022-0981(95)00156-5

Slattery M, and Lesser MP. 2015. Trophic ecology of sponges from shallow to mesophotic depths (3 to $150 \mathrm{~m}$ ): Comment on Pawlik et al.(2015). Marine Ecology Progress Series 527:275-279.

Stocking JB, Rippe JP, and Reidenbach MA. 2016. Structure and dynamics of turbulent boundary layer flow over healthy and algae-covered corals. Coral Reefs:1-13. $10.1007 / \mathrm{s} 00338-016-1446-8$

Tanaka Y, Miyajima T, Watanabe A, Nadaoka K, Yamamoto T, and Ogawa H. 2011. Distribution of dissolved organic carbon and nitrogen in a coral reef. Coral Reefs 30:533541. 10.1007/s00338-011-0735-5 
490 Torréton J, Pagès J, Dufour P, and Cauwet G. 1997. Bacterioplankton carbon growth yield and 491 DOC turnover in some coral reef lagoons. Proc 8th Int Coral Reef Symp. p 947-952. 492 Van Duyl FC. 1985. Atlas of the living reefs of Curaçao and Bonaire (Netherlands Antilles). 493 Utrecht.

494 Van Duyl FC, and Gast GJ. 2001. Linkage of small-scale spatial variations in DOC, inorganic 495 nutrients and bacterioplankton growth with different coral reef water types. Aquatic $496 \quad$ Microbial Ecology 24:17-26. 10.3354/ame024017

497 Vermeij MJA, and Bak RPM. 2002. How are coral populations structured by light? Marine light 498 regimes and the distribution of Madracis. Marine Ecology Progress Series 233:105-116. $499 \quad 10.3354 / \operatorname{meps} 233105$

500 Vermeij MJA, and Bak RPM. 2003. Species-Specific Population Structure of Closely Related $501 \quad$ Coral Morphospecies Along a Depth Gradient (5 - 60 M) Over a Caribbean Reef Slope. 502 Bulletin of Marine Science 73:725-744.

503 Veron JEN. 2000. Corals of the World, vol. 1-3. Australian Institute of Marine Science, 504 Townsville.

505 Wild C, Laforsch C, Mayr C, Fuß R, and Niggl W. 2012. Effect of water currents on organic 506 matter release by two scleractinian corals. Aquatic Ecology 46:335-341. 10.1007/s10452012-9404-1

Yahel G, Sharp JH, Marie D, Häse C, and Genin A. 2003. In situ feeding and element removal in 509 510 the symbiont-bearing sponge Theonella swinhoei: Bulk DOC is the major source for carbon. Limnology and Oceanography 48:141-149. 10.4319/1o.2003.48.1.0141 